\title{
National Library Week Suggestions
}

\author{
Penny E. Elkins \\ DuPont Library \\ University of the South
}

Public libraries no longer have a corner on the market for National Library Week, April 8-14, 1984. At long last, academic libraries are realizing the potential of public relations to celebrate this week and promote the library all year long. Last year the Paul Meek Library, University of Tennessee at Martin (UTM), celebrated NLW with a different event each day.

We began the week with a treat for our staff and student workers - homemade cookies in bags trimmed with national library symbol tags that proclaimed "Happy National Library Week!” On Tuesday we extended the celebration to the campus by distributing bookmarks with trivia questions that could be answered using reference books. On Wednesday we sent the faculty and administration multi-colored flyers incorporating the NLW slogan, "If you want to read it, hear it, see it, learn it or improve upon it then 'Go for it!' at the Paul Meek Library." Our library was decorated with brightly colored helium balloons on Thursday. Each balloon had a matching tag advertising NLW. We ended the week with refreshments for the staff. The lounge was decked out with balloons and streamers centering around the national library symbol. Refreshments included cakes decorated with the "Go for it!" slogan and the arrow symbol.

Throughout the week staff members wore name tags announcing National Library Week. We incorporated UTM's school colors and various library slogans (Go for it!; Check it out at the library; Jog your mind at the library) to make some eyecatching tags. Another NLW project was to play ALA spots on the campus radio station, where we now advertise our services year round.

Plans for this year's National Library Week include more involvement of students and faculty. Working with the theme "Knowledge is Real Power!" we will build displays illustrating academic library resources. We are focusing on areas of special interest to our students and faculty, including computers, job markets, rock music, cars, fashion, agriculture and the communications industry.

We hope to involve students and other patrons further with contests, quizzes and coupons. One possible activity is a treasure hunt. Leave clues in the card catalog or periodicals file, sending patrons to specific books or journals where they may find further clues or prizes. The search is exciting and involves library skills. Money and gift certificates from local merchants and restaurants would be at- tractive prizes for students.

Contests draw people into the library. Ask patrons to guess how many books were checked out on a certain day, how many people came into the library, etc., and give prizes for the correct answer. In general, any type of contest or marathon event that works for other organizations on campus will be an equally effective public relations tool for the library.

The library may also advertise in the campus newspaper, sponsoring coupons for discounts on xerox charges, laminating services and book fines or for free hours in the library typing room. Coupons redeemable off-campus for food, record albums and film or concert tickets are especially appealing.

Full-time public relations makes a solid foundation for a positive image of the academic library. Bookmarks, displays, annual reports, name tags, newsletters and ALA posters are effective, constant reminders that the library is the place to become more knowledgeable-and we all know that "Knowledge IS Real Power!"

Editor's Note: This article has been reprinted from the ALA Public Information Office's publication, Power Tools Publicity Book 1984: Ideas for National Library Week and All Year Long.

\section{MLA Special Sessions Needed}

Librarians wishing to organize Special Sessions for the December 1984 conference of the Modern Language Association must submit proposals to MLA's Program Committee by April 9, 1984. The 75-minute long sessions should appeal to the teaching and research interests of faculty in the fields of language and literature in some concrete way, and should not be related solely to library concerns. Instructional and online topics are particularly germane.

Session organizers and participants must all be members of MLA by April 1, 1984. Faculty participants would be an asset, and their participation in the program can be solicited through the MLA Newsletter as well as through personal contact. For more information and proposal application forms, contact the MLA at 62 Fifth Avenue, New York, NY 10011, or write to Bill Miller, Michigan State University Libraries, East Lansing, MI 48824-1048. 